\title{
SISTEM PENGHANTARAN OBAT MELEWATI BARRIER DARAH OTAK
}

\author{
Yandi Syukri \\ Laboratorium Teknologi Farmasi Universitas Islam Indonesia Jogjakarta
}

\begin{abstract}
Brain barrier is effective barrier in drug delivery to brain. For effectiveness drug delivery need be desaigned a delivery with nanoparticle technology. Nanoparticles are solid colloidal particles ranging in size from 1 to $1000 \mathrm{~nm}$ that are utilized as drug delivery agents. The primary advantages of nanoparticle carrier technology is that nanoparticles mask the blood - brain barrier limiting characteristics of the therapeutic drug molecule. Furthermore, this system may slow drug release in the brain, decreasing peripheral toxicity. The method which elaboration in manufacture nanoparticles are emulsion polimerization, interfacial polimerization, desolvation evaporation and solvent deposition. Currently, report evaluating nanoparticles for brain delivery have studied anesthetic and chemoterapeutic agent. These studies are reviewed for efficacy and mechanisms of transport. Physiological factors such as phagocytic activity of the reticuloendothelial system and protein opsonization may limit the amount of brain delivered drug. Nanoparticle technology appears to have significant promise in delivering therapeutic molecules across the blood-brain barrier.
\end{abstract}

Key Word : Drug Delivery System, Nanoparticle, Blood-Brain Barrier.

\section{PENDAHULUAN}

Barrier otak merupakan penghalang yang efektif dalam penghantaran obat menuju otak. Untuk keefektifan terapi perlu dirancang suatu sistem penghantaran obat yang dapat meningkatkan permeabilitas membran otak yang mana obat dihantarkan menuju sasaran (drug targetted system) yang akan mengontrol sistem penghantaran obat. Salah satu metode yang dikembangkan dalam penghantaran obat menuju sasaran dan sekaligus meningkatkan konsentrasi darah di otak adalah teknologi nanopartikel.

Nanopartikel merupakan partikel koloid padat dengan ukuran 1 sampai $1000 \mathrm{~nm}$, terdiri dari makromolekul yang bervariasi yang mana efek obat bisa diabsorpsi, diperangkap atau diikat secara kovelen. Satu kegunaan nanopartikel adalah memfasilitasi pembawa penghantaran obat baru ke jaringan melalui tubuh. Mekanismenya adalah dengan menutupi barrier membran, memelihara stabilitas obat karena sifatnya sebagai pembawa obat koloid. Sewaktu nanopartikel mencapai jaringan yang diinginkan, obat akan dilepaskan secara desoprsi, difusi melalui matrik nanopartikel atau dinding polimer, dengan erosi nanopartikel, atau beberapa kombinasi dari salah satu atau keseluruhan mekanisme.

\section{STRATEGI UNTUK MENINGKATKAN PENGHANTARAN OBAT MENUJU SISTEM SYARAF PUSAT}

Banyak faktor yang perlu dipertimbangkan selama pengembangan obat yang mengandung nanopartikel. Tabel I mengilustrasikan persyaratan untuk polimer NP dalam penghantaran obat menuju sistem saraf pusat. 
Tabel I. Sifat-sifat ideal dari polimer nanopartikel untuk penghantaran obat melintasi barrier darah otak.

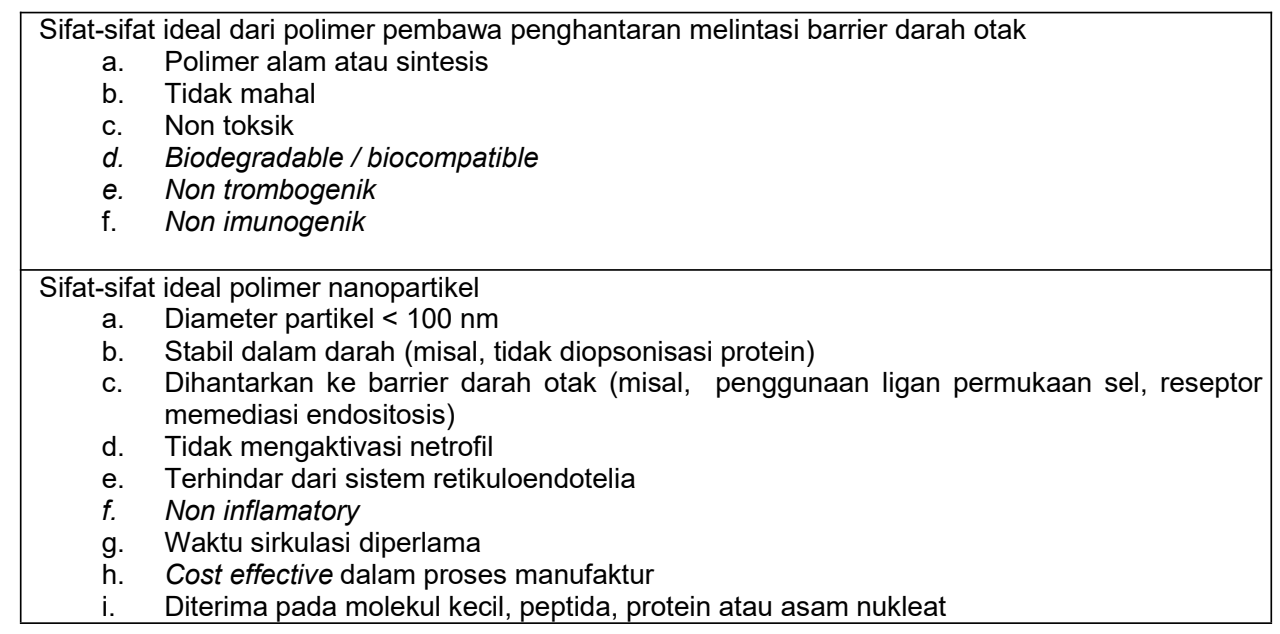

Barrier didefinisikan sebagai pemindahan yang terbatas dari senyawa hidrofilik, protein-protein kecil dan molekul-molekul bermuatan antara plasma dan sistem saraf pusat. Barrier darah otak terdiri dari suatu lapisan berdekatan dari sel endotelial yang dihubungkan oleh tight junction yang mengelilingi keseluruhan batas sel pada kapiler otak.

Karena karakteristik barrier darah otak menyediakan suatu penghalang yang hebat untuk terapi obat pada sistem saraf pusat maka perlu upaya untuk mengatasinya. Diantaranya adalah perubahan integritas atau karakteristik barrier, atau perubahan karakteristik dari obat. Gambar 1 mengilustrasikan strategi yang digunakan untuk meningkatkan penghantaran obat menuju sistem saraf pusat.

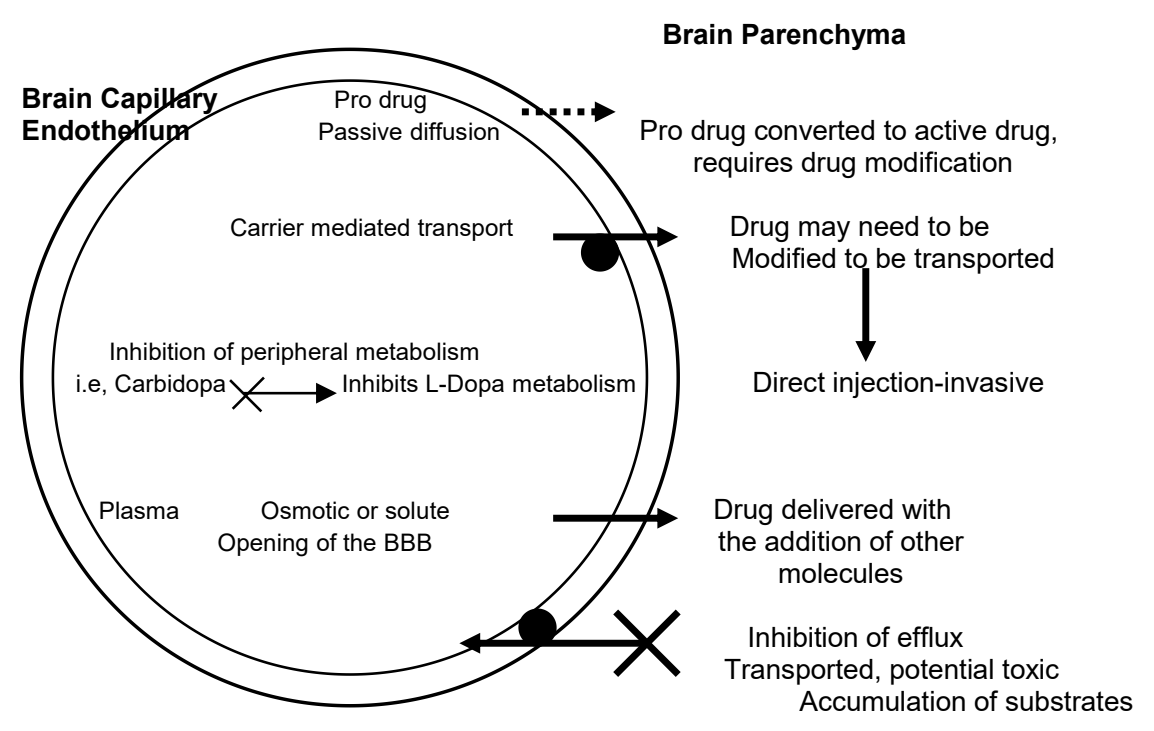

Gambar 1. Strategi untuk meningkatkan penghantaran obat menuju sistem saraf pusat 
Pro-drug merupakan suatu contoh dari beberapa manipulasi obat. Pada metode ini senyawa asli dimanipulasi untuk membuatnya lebih larut dalam lipid, sehingga penetrasinya lebih besar menuju sistem saraf pusat. Walaupun pro drug telah terbukti dengan baik, namun tidak semua senyawa (misal neurotrophic factors) bisa dimanipulasi dengan cara ini. Selanjutnya, peningkatan kelarutan dalam lipid akan merubah parameter farmakokinetika secara signifikan seperti kliren dan waktu paro.

Alternatif lain untuk penghantaran obat menuju otak adalah penggunaan carrier asli yang ditujukan pada barrier darah otak. Carrier, telah diketahui sebagai transporter, menghantarkan hidrofilik esensial dan senyawa besar melintasi barrier seperti kolin, purin, asam amino dan lipoprotein. Sebagai contoh, senyawa kemoterapetik D, L-NAM (untuk tumor otak) ditranspor melintasi barrier darah otak dengan carrier asam amino netral. Untuk keefektifan penghantaran obat-obat harus mempunyai carrier spesifik, jadi karakteristik molekularnya terbatas. Nanopartikel bisa melewati barrier darah otak secara difusi pasif atau reseptor yang memperantarai endositosis yang melintasi barrier darah otak tanpa menyediakan molekul obat spesifik.

Injeksi secara langsung kedalam otak merupakan pendekatan lain untuk menghindari barrier darah otak. Contohnya adalah pada pasien Alzheimer dengan infus intracerebroventrikular kedalam cairan cerebrospinal, inplantasi langsung kedalam parenkim dari suatu matrik polimer yang mengandung faktor pertumbuhan (growth factor).

Penggunaan nanopartikel sebagai carrier obat koloidal mempunyai suatu keuntungan untuk menghindari barrier darah otak. Review ini akan mendiskusikan peran nanopartikel dalam kaitannya untuk peningkatan penghantaran melintasi barrier darah otak, metode utama penyiapan, penelitian yang dipublikasikan pada penghantaran nanopartikel pada otak dan sistem retikuloendotelial sebagai suatu halangan penghantaran menuju sistem saraf pusat.

\section{METODE MANUFAKTUR.}

Metode-metode utama manufaktur nanopartikel adalah sebagai berikut :

1. Polimerisasi emulsi (emulsion polymerization)

2. Polimerisasi antarmuka (interfacial polymerization)

3. Penguapan desolvasi (desolvation evaporation)

4. Deposisi pelarut (solvent deposition)

Pemberian obat bisa dilakukan dengan absorpsi, adsorpsi dan enkapsulasi, sebagaima tersaji pada gambar 2 berikut.

\section{Brain Parenchyma}

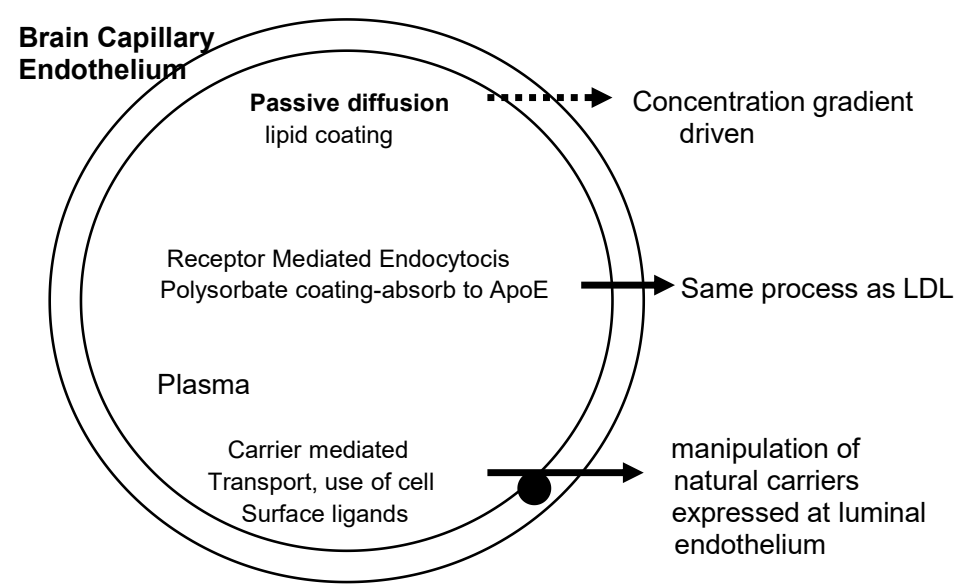

Gambar 2. Beberapa tipe dari pemberian obat nanopartikel untuk penghantaran menuju sistem saraf pusat 


\section{Polimerisasi emulsi (emulsion polymerization)}

Emulsi polimerisasi mencirikan kedua polimerisasi radikal dan anionik, merupakan satu dari banyak teknik untuk menghasilkan nanopartikel. Proses terdiri dari bangunan suatu rantai polimer, yang bekerja sebagai carrier obat dari unit monomer tunggal pada senyawa yang diberikan. Polimerisasi terjadi secara spontan pada suhu kamar setelah inisiasi dengan radikal bebas atau pembentukan ion. Pencetus pertumbuhan polimer melibatkan energi radiasi yang tinggi, sinar UV atau ion-ion hidroksil. Ketika polimerisasi selesai, larutan disaring dan dinetralkan untuk menghilangkan sisa monomer. Masa dari polimer tipe formulasi nanopartikel menyediakan suatu tempat yang bekerja sebagai carrier untuk absorpsi dan adsorpsi dari obat (gambar 2A dan B)

Emulsi polimerisasi mempunyai beberapa keuntungan dalam formulasi nanopartikel. la lebih cepat dibandingkan metode lain, stabilizer dan surfaktan secara umum tidak dibutuhkan dan mudah untuk scale up pada manufaktur. Emulsi polimerisasi bisa juga dikerjakan dalam suatu fase organik dari suatu fase cairan. Proses ini telah dicobakan untuk pembuatan nanopartikel polialkil-sianoakrilat.

Kerugian utama dari emulsi polimerisasi adalah membutuhkan radikal bebas, radiasi atau sinar UV untuk pencetus (trigger) polimerisasi. Pencetus-pencetus ini menghalangi penggabungan peptida dan protein selama polimerisasi. Jadi untuk memelihara stabilitas penggabungan protein dan peptida, nanopartikel harus dimurnikan dengan dialisis dan sentrifugasi untuk menghilangkan sisa monomer. Kerugian berikutnya adalah dibutuhkannya sejumlah besar pelarut organik sehingga potensial untuk toksik.

\section{Polimerisasi Antarmuka}

Polimerisasi antarmuka sama dengan polimerisasi emulsi dimana monomer-monomer digunakan untuk membuat polimer, meskipun mekanismenya berbeda. Polimerisasi antarmuka terjadi ketika suatu fase air dan fase organik diperlakukan bersamaan dengan homogenisasi, emulsifikasi atau micro-fluidization dibawah putaran mekanik yang kuat. Polimerisasi ini menghalangi inklusi dari peptida/protein pada langkah sekunder pada putaran mekanik. Sebagai contoh pembuatan nanokapsul polialkilsianoakrilat (gambar 2C) dilakukan ketika monomer dilarutkan dalam minyak dan penambahan fase air perlahan melalui suatu tabung kecil dengan pengadukan konstan. Monomer kemudian secara spontan membentuk kapsul $200-300 \mathrm{~nm}$ dengan polimerisasi anionik. Penggabungan obat terjadi dengan penambahan obat dengan monomer dalam fase organik. Obat yang didorong ini dibungkus dalam matrik dari nanopartikel.

Suatu subset polimerisasi antarmuka adalah proses penambahan suatu campuran pelarut dari benzil benzoat, aseton dan fosfolipid pada fase organik yang mengandung obat dan monomer. Telah dibuktikan bahwa proses ini mendorong pembentukan kulit nanokapsul antara fase air dan tetesan benzil benzoat dalam fase organik. Satu keuntungan dari polimerisasi antarmuka memungkinkan enkapsulasi obat. Saat obat dienkapsulasi, ia dilindungi sampai mencapai jaringan target dan degradasi yang terjadi. Dalam kasus penghantaran pada sistem saraf pusat, polimerisasi diperlukan untuk melindungi atau menyembunyikan obat sampai melewati barrier dan bisa dilepaskan kedalam otak.

\section{Denaturasi dan Desolvasi}

Makromolekul seperti albumin dan gelatin bisa juga digunakan untuk menghasilkan nanopartikel. Dua proses utama yaitu denaturasi minyak dan desolvasi digunakan untuk memproses makromolekul sebagai nanopartikel. Denaturasi emulsi minyak merupakan proses dimana makromolekul besar diperangkap (trapped) dalam fase organik dengan homogenisasi. Sewaktu trapped, makromolekul dimasukkan perlahan kedalam fase air dengan pengadukan konstan. Partikel-partikel dibentuk dengan memasukkan dua fase tak bercampur kemudian dibekukan dengan crosslinking dengan suatu aldehid atau denaturasi panas. Pengaruh yang paling besar terlihat pada sifat-sifat dan tipe dari minyak yang digunakan.

Makromolekul bisa juga membentuk nanopartikel dengan desolvasi. Desolvasi terjadi ketika makromolekul dilarutkan dalam pelarut dimana makromolekul berada dalam suatu sistem pengembangan (swollen) yaitu pembentukan gulungan (coiled comformation). Makromolekul yang mengembang kemudian dimasukkan pada gulungan (coil) yang rapat dengan merubah lingkungan $\mathrm{pH}$, muatan atau penggunaan senyawa desolvasi seperti etanol. Obat selanjutnya terikat pada protein atau makromolekul sehingga terjadi entrapped dalam bentuk partikel baru. Makromolekul kemudian dipadatkan dengan metode crosslinking dengan suatu aldehid. Kekurangan utama dari metode ini adalah jumlah nanopartikel dan obat yang diabsorpsi sangat sedikit dibandingkan metode lain. Solid lipid nanopartikel dihasilkan dengan homogenisasi pada temperatur tinggi. 


\section{MEKANISME TRANSPOR NANOPARTIKEL MELINTASI SAWAR DARAH OTAK}

Pada umumnya transfer obat melewati barrier darah otak terjadi secara difusi pasif transpor yang difasilitasi carrier. Difusi pasif terjadi bila obat larut dalam membran lipid dari sel cerebrovascular endotelial dan kemudian dilepaskan kedalam otak. Difusi pasif tergantung pada lipofilisitas obat, muatan, gradien konsentrasi, berat molekul dan derajat ikatan protein yang dikarakteristikkan dengan Hukum Fick untuk difusi :

$-d C / d t=k\left(C_{1}-C_{2}\right)$

Transpor obat melintasi barrier darah otak tergantung pada protein carrier pada sel kapiler endotelial. Transpor yang diperantarai carrier terjadi secara transpor fasilitatif berhubungan dengan gradien konsentrasi, transpor aktif (melawan gradien konsentrasi) dan endositosis.

Mekanisme pelepasan nanopartikel menuju sistem saraf pusat dapat dilihat pada gambar 3 berikut.

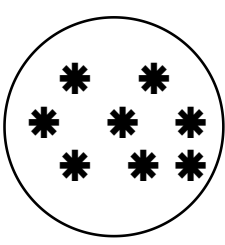

A

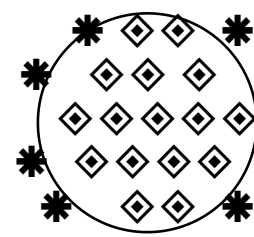

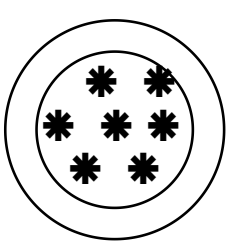

C

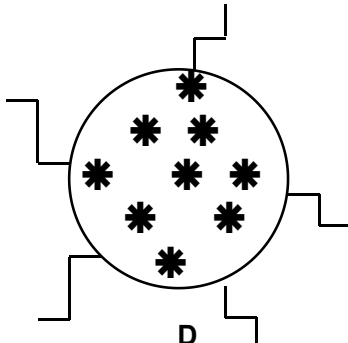

D

A. Solid colloidal NP with homogenous dispersion of drug

B. Solid NP with drug associated on exterior

C. Nanocapsule with dreg entrapped

D. Solid colloidal NP with homogenous dispersion of drug and cell surface ligand * Drug

$$
\text { Polymeric Matrix }
$$

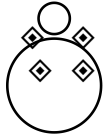

Solid NP

Cell surface ligand

Gambar 3. Mekanisme pelepasan nanopartikel menuju sistem saraf pusat

\section{PENGGUNAAN NANOPARTIKEL PADA ANESTESI}

Baru-baru ini dipublikasikan penggunaan nanopartikel untuk meningkatkan distribusi obat ke otak yang mengandung senyawa seperti dalagrin, kitorpin dan senyawa neuromuskular penghambat tubokurarin (neuromuscular blocking agent tubocurarine). Anestesi ini dipilih karena dapat meningkatkan efek terapi karena obat dapat langsung dihantarkan ke otak dibandingkan dengan pemberian periferal yang tidak memberikan efek anestesi. Ini membuktikan bahwa anentesi-anestesi ini tidak dapat melintasi barrier darah otak dengan baik dari plasma. 
Nanopartikel polibutilsianoakrilat yang disalut dengan polisorbat-80 telah memperlihatkan penghantaran dalagrin polipeptida melintasi barrier darah otak setelah injeksi intravena. Dalagrin tanpa modifikasi tidak mampu melintasi barrier darah otak. Apabila dalagrin diadsorpsi pada nanopartikel polibutilakrilat yang disalut dengan polisorbat-80 sebagai surfaktan, terlihat suatu kerja anestesi yang lama dan signifikan setelah pemberian intravena. Selanjutnya, bila dalagrin diadsorpsi pada polibutilsianoakrilat tanpa penyalutan surfaktan, tidak terlihat efek analgesiknya.

\section{PENGGUNAAN NANOPARTIKEL DALAM PENGOBATAN KEMOTERAPETIK}

Banyak obat-obat kemoterapetik merupakan molekul polar dan tidak mampu dengan cepat berpenetrasi menuju barrier darah otak. Padahal untuk kemoterapi sel kanker oleh senyawa antikanker dibutuhkan waktu yang lama dan konsentrasi yang optimal. Bila kedua faktor ini dimaksimalkan untuk menyediakan kemanjuran terapi dan konsentrasi plasma tinggi akan menghasilkan toksisitas sistemik yang signifikan. Nanopartikel sebagai carrier kemoterapi telah dipelajari sebagai suatu solusi permasalahan diatas.

Doxorubicin, suatu antibiotika antrasiklin, merupakan suatu senyawa kemoterapi yang mampu melakukan interkalasi dengan DNA, sehingga menghasilkan suatu penghambatan sintesis DNA. Doxorubicin merupakan melekul polar yang secara normal tidak melintasi barrier darah otak. Apabila doxorubicin diberikan secara intravena diadsorpsi pada nanopartikel polibutilsianoakrilat dengan polisorbat-80 sebagai surfaktan, maka konsentrasi doxorubicin pada sistem saraf pusat ada pada daerah terapi.

Camphotericin suatu obat antikanker lipofilik diadsorpsi pada nanopartikel solid lipid, pelepasan obat secara in vitro sampai 1 minggu pada tikus. AUC dan mean resindence time nanopartikel solid lipid camphotericin lebih tinggi dibandingkan kontrol pada organ otak, jantung dan sel retikuloendotelial. Nanopartikel solid lipid merupakan suatu sustained release dan sistem drug-targeting yang menjanjikan untuk obat-obat antitumor lipofilik pada sistem saraf pusat.

Penghantaran obat antitumor dengan nanopartikel merupakan suatu alternatif yang menjanjikan dibandingkan dengan pembedahan atau injeksi langsung obat pada sistem saraf pusat. Satu keuntungan dari terapi antitumor dengan nanopartikel sebagai carrier obat adalah memperlama mean residence time dalam tubuh. Sebaliknya kerugiannya adalah memungkinkan peningkatan tumor pada senyawa kemoterapi, ia juga memperlama sisa obat dalam tubuh sehingga potensial meningkatkan toksisitas. Contoh dari penggunaan nanopartikel untuk penghantaran obat melintasi Blood Brain Barrier dapat dilihat pada tabel II berikut.

Tabel II. Contoh penggunaan nanopartikel dalam penghantaran obat melintasi BBB

\begin{tabular}{|l|l|l|l|l|}
\hline \multicolumn{1}{|c|}{ Obat } & \multicolumn{1}{|c|}{ Tipe NP } & \multicolumn{1}{c|}{ Polimer/ Stabilizer } & \multicolumn{1}{c|}{ Surfaktan } & \multicolumn{1}{c|}{ Hasil } \\
\hline Champotericin & Solid lipid NP & Minyak kedele & Poloxamer & $\begin{array}{l}\text { Meningkatkan AUC } \\
\text { di otak 10,4 kali }\end{array}$ \\
\hline Albumin & $\begin{array}{l}\text { Inti } \\
\text { polisakarida }\end{array}$ & Maltodekstrin & $\begin{array}{l}\text { Lipid } \\
\text { coating-dipamito } \\
\text { yl }\end{array}$ & $\begin{array}{l}\text { 27 kali meningkatkan } \\
\text { trnaspor melintasi } \\
\text { BBB secara in vitro }\end{array}$ \\
\hline Dalagrin & Solid NP & Polibutilsianoakrilat & Polisorbat-80 & $\begin{array}{l}\text { Meningkatkan daya } \\
\text { anelgesik 50\% }\end{array}$ \\
\hline Amitriptilin & Solid NP & $\begin{array}{l}\text { Polibutilsianoakrilat/de } \\
\text { kstran70 } \\
\text { polisorbat-85 kDa }\end{array}$ & Tidak disalut & $\begin{array}{l}\text { Meningkatkan AUC } \\
\text { di otak 50\% \% }\end{array}$ \\
\hline Soxorubicin & Solid lipid NP & Asam stearat & Epikuron 200 & $\begin{array}{l}\text { Level plasma 1/4 } \\
\text { setelah pemberian 4 } \\
\text { jam sedangkan 0 } \\
\text { tanpa carrier }\end{array}$ \\
\hline
\end{tabular}




\section{SISTEM RETIKULOENDOTELIAL, SUATU PENGHALANG PENSASARAN OBAT (DRUG TARGETING) DI SISTEM SARAF PUSAT.}

Awalnya, pensasaran nanopartikel pada otak terbukti tidak berhasil bila diberikan secara intravena. Kegagalan nanopartikel mencapai sistem saraf pusat dalam jumlah besar dikarenakan uptake sistem retikuloendotelial yang juga diketahui sebagai sistem fagositas minonuklear. Sistem retikuloendotelial merupakan kelompok sel mononuklear dari sumsum tulang yang mempunyai respon fagositas yang mengeluarkan partikel kecil yang bukan merupakan bagian vaskular. Sistem retikuloendotelial secara signifikan mengembalikan sejumlah besar (sampai 80 - $85 \%$ ) nanopartikel dari bagian vaskular, yang membatasi pemaparan nanopartikel pada cerebrovasculature dan menghasilkan penurunan konsentrasi obat pada otak

Strategi untuk mengatasi uptake sistem retikuloendotelial melibatkan guidance external dari nanopartikel yang merespon secara magnetik dan menyalut nanopartikel dengan antibodi atau surfaktan hidrofilik. Guidance magnetik terdiri dari pembuatan nanopartikel yang mengandung magnetit $\left(\mathrm{Fe}_{3} \mathrm{O}_{4}\right)$ dan menggunakan suatu magnet eksternal. Sebagai contoh, doxorubicin dimasukkan kedalam nanopartikel magnetik ini. Apabila suatu magnet (3000 gauss) ditempatkan dekat ekor tikus, terjadi peningkatan 24 kali lipat AUC yang diperoleh jika dibandingkan obat bebas. Medan magnet menghasilkan peningkatan konsentrasi otak dan menurunkan konsentrasi jaringan non target.

Solusi lain untuk problem dari uptake yang cepat dari nanopartikel oleh sistem retikuloendotelial adalah menyalut dengan surfaktan. Surfaktan utama yang digunakan adalah polaxamin 908 dan polisorbat-80. Pengurangan uptake sistem retikuloendotelial dari nanopartikel oleh hati dan organ-organ lain dari retikuloendotelial akan menghasilkan peningkatan residence time dari obat dalam sirkulasi dan meningkatkan uptake organ non-sistem retikuloendotelial.

Polisorbat-80 telah digambarkan efektif dalam meminimalkan uptake oleh organ yang ditempati sistem retikuloendotelial. Apabila nanopartikel yang mengandung doxorubicin diberikan secara intravena dengan dan tanpa surfaktan, terdapat perbedaan yang signifikan. Perubahan karakteristik permukaan nanopartikel dengan surfaktan meningkatkan kemampuan nanopartikel mencapai barrier darah otak, tanpa meningkatkan uptake oleh sistem retikuloendotelial.

Dapat disimpulkan, aktifitas fagositas dari keberadaan sistem retikuloendotelial suatu penghalang dalam penghantaran nanopartikel menuju otak. Beberapa peneliti mengatasi problem ini dengan memanipulasi kandungan nanopartikel (magnetik) atau penambahan surfaktan (poloxamin dan polisorbat-80).

\section{KESIMPULAN}

Telah dibuktikan bahwa nanopartikel dapat melintasi barrier dengan difusi pasif dan reseptor yang diperantarai endositosis. Selanjutnya, penghantaran secara langsung ke otak memungkinkan penggunaan ligan dengan afinitas yang tinggi pada permukaan nanopartikel sebagai transporter barrier darah otak. Salah satu keuntungan dari sistem ini adalah obat dapat dilepaskan secara lambat dan terkontrol langsung menuju jaringan target sehingga menghindari organ-organ lain, sehingga akan mengurangi toksisitas perifer atau sistemik.

Secara langsung, penelitian ini telah difokuskan pada senyawa anestesi dan kemoterapi. Penggunaan anestesi merupakan suatu pilihan yang baik untuk penelitian dasar dari nanopartikel melintasi barrier darah otak. Studi dari nanopartikel yang diberikan pada senyawa kemoterapi bertujuan untuk terapi kanker di sistem saraf pusat. Nanopartikel dapat meningkatkan AUC otak pada doxorubicin dan camphotericin. Selanjutnya studi bisa dikembangkan dengan mempertimbangkan evaluasi dari penyakit sistem saraf pusat lainnya dan hanya dibatasi pada pengobatan terapi pada barrier darah otak. 


\section{DAFTAR PUSTAKA}

Bloom, F.E., 1996, Neurotransmission and The Central Nervous System, in Goodman \& Gilman The Pharmacological Basis of Therapeutics, The McGraw-Hill Companies, USA

Jatnzen, G.M., Robinson, J.R, 1996, Suntaned and Controlled Release Drug Delivery System, In Modern Pharmaceutics, Banker and Rhodes, Eds, Marcel Dekker, Inc, New York

Kumar, V., Banker, G.S., 1996, Target-Oriented Drug Delivery System, In Modern Pharmaceutics, Banker and Rhodes, Eds, Marcel Dekker, Inc, New York

Kreuter, J., 1996, Nanoparticles, In Encyclopedia of Pharmaceutical Technology, Swabrick, J., Boylan, J.C, Eds., Marcel Dekker, New York.

Lockman, P.R., Mumper, R.J., Khan, M.A., Allen, D.D, 2002, Nanoparticle Technology for Drug Delivery Across the Blood-Brain Barrier, Drug Dev. Ind. Pharm, 28(1), 1-12 